\title{
How spiritual leadership and organizational culture influence employee performance?
}

\author{
Fajar Surya Ari Anggara* \\ Universitas Darussalam Gontor (Kabupaten Ponorogo, 63471, Indonesia) \\ fajarsurya@unida.gontor.ac.id \\ Alfin Aulia \\ Universitas Darussalam Gontor (Kabupaten Ponorogo, 63471, Indonesia) \\ alfin.aulia.unida@gmail.com \\ *Penulis Korespondensi
}

Submitted: Sept 14, 2020; Reviewed: Sept 15, 2020; Accepted: May 06, 2021

\begin{abstract}
Spiritual leadership management is causal leadership for organizations designed to produce educational organizations that are intrinsically motivated. The aim of spiritual leadership is to produce a strategic and empowered vision and value appropriateness of team-level values and people and, in its words, greater responsiveness and organizational productivity. Organizational culture is a perception that is made jointly by members of the organization and must be obeyed by members of the organization or it is called a system created for togetherness. To achieve economic independence, Darussalam Gontor University established a business unit, namely the UNIDA Business Unit (U3). The Darussalam Gontor University Business Unit is one of the business fields owned by the Darussalam Gontor University with employees of different backgrounds. This study aimed to analyze the influence of organizational culture and spiritual leadership on the performance of employees of the Darussalam Gontor University Business Unit. This type of research was a quantitative study with a total of 49 respondents. The population of this study were all employees of the Darussalam Gontor University Business Unit which included managers, staff, and operational employees. The technique used was multiple linear regression analysis techniques. Data obtained through respondents with a survey in the form of a questionnaire and measured using a Likert scale. The results showed that organizational culture has a positive and insignificant effect on employee performance. Meanwhile, spiritual leadership has a positive and significant effect on employee performance.
\end{abstract}

Keywords: business unit; employee performance; organizational culture; spiritual leadership; university of Darussalam Gontor Abstrak: Kepemimpinan spiritual dalam organisasi yang dirancang untuk menghasilkan organisasi
pendidikan yang termotivasi secara intrinsik. Tujuan dari kepemimpinan spiritual merupakan untuk
menghasilkan visi dan kesesuaian nilai tingkatan kelompok sekumpulan orang. Pendekatan strategis
kepemimpinan spiritual dan budaya organisasi dapat memberikan luaran produktivitas organisasi
yang lebih besar. Budaya organisasi merupakan suatu presepsi yang dibuat bersama oleh anggota
organisasi dan wajib dipatuhi oleh anggota organisasi atau dinamakan suatu sistem yang dibuat
untuk kebersamaan. Prinsip kemandirian ekonomi dalam lembaga pendidikan yang berlatar
pesantren perlu didukung dengan kepemimpinan spiritual dan budaya organisasi yang khas dalam
mengelola kegiatan produksi, distribusi, dan konsumsi sehingga potensi kegiatan ekonomi selalu aktif
berputar di dalam lembaga pendidikan dapat dimanfaatkan untuk kampus pesantren seperti UNIDA
Gontor. Untuk mewujudkan kemandirian ekonomi lembaga pendidikan, Universitas Darussalam
DoI: https://doi.org/10.28932/jmm.v20i2.2939 
Gontor mendirikan unit usaha, yaitu Unit Usaha UNIDA (U3). Unit Usaha Universitas Darussalam Gontor merupakan salah satu bidang usaha yang dimiliki oleh Universitas Darussalam Gontor memiliki karyawan berlatar belakang berbeda. Penelitian ini bertujuan untuk menganalisa pengaruh budaya organisasi dan kepemimpinan spiritual terhadap kinerja karyawan Unit Usaha Universitas Darussalam Gontor. Jenis penelitian ini adalah penelitian kuantitatif dengan jumlah responden sebanyak 49 orang responden. Populasi penelitian ini adalah seluruh karyawan Unit Usaha Universitas Darussalam Gontor yang mencakup manajer, staff, dan karyawan operasional. Teknik yang digunakan adalah teknik analisis regresi linier berganda. Data diperoleh melalui responden dengan survei berupa kuisioner dan diukur menggunakan skala Likert. Hasil menunjukkan bahwa budaya organisasi berpengaruh positif dan tidak signifikan terhadap kinerja karyawan. Sedangkan, kepemimpinan spiritual berpengaruh positif dan signifikan terhadap kinerja karyawan.

Kata kunci: budaya organisasi; kepemimpinan spiritual; kinerja karyawan; unit usaha; universitas Darussalam Gontor

\section{INTRODUCTION}

Organizational culture can be strength and weak. Organizational culture becomes a strength for organizations if culture can support the process of communication, the course of supervision and foster a spirit of work, and increase the commitment of organizational members to organizations to advance and improve organizational efficiency (Mehta \& Joshi, 2010). Organizational culture phenomenon such as few workers are less capable, bringing about terrible showing in completing the work (Kuswati, 2020).

In the era of globalization, Indonesia is being hit by a leadership crisis, characterized by various problem and bureaucratic performance, which in general makes the image of leadership look weak in the eyes of the wider public. U3 (Unit Usaha UNIDA) is a business unit of University of Darussalam Gontor that the staff has a diverse background. This makes employees' understanding of organizational culture and spiritual leadership have a view from their point of view. It needs to be taught based on analysis of spiritual leadership, organizational culture, employee performance, in order to understand, think, and feel about the problem (Violita, 2018). Based on the above understanding, researchers took five basics as indicators of this study because the five souls are values created and found by individuals or groups used as evidence for organizations and employees should follow the values that have been instilled. Organizational culture as a coupling interest for its individuals since it is arranged in different principles of the organization (Kuswati, 2020). Spiritual leadership is making a vision to involvement of calling, reason, and meaning, and setting up an organizational culture based on the spiritual value (Samul, 2020).

Based on research conducted by Samul (2020), there is a conceptual framework between organizational culture and spiritual leadership. The result of the other research found that the organization's culture is one of the most important components of the institution's internal environment, which influences the culture and performance of human resources and it is an important impetus towards achievement (Alimudin et al., 2017). The result of this research is that the culture of the organization has a positive and insignificant effect on employee performance at Bank BRI Syariah Semarang Branch Office (Soleh, 2018). Although the idea of spiritual leadership is still emerging, many organizations are using this type of leadership as well as productivity, employee satisfaction, employee commitment, and profit (Scott \& Tweed, 2016). Spiritual values of integrity, honesty and humility, as well as spiritual application in treating others with respect and fairness, a feeling of care and attention, responding, respecting others, and leaving time for individual reflection related to positive impacts that can be measured for organizations as well as people (Reave, 2005).

U3 is a business unit owned by University of Darussalam Gontor. In this business unit, it has a different staff background. Panca Jiwa is one of the values of Darussalam Gontor University. One of the economic principles developed by UNIDA Gontor is the economy of protection. This principle aims to protect financial turnover internally. So that the finances that always revolve around the campus environment can be used for the benefit of the campus itself. To realize such an economic 
system, UNIDA Gontor established a business unit, namely the Unit Usaha UNIDA (U3). Spiritual leadership has a positive relationship with employee job performance, knowledge sharing, and innovation attitudes, when we assist, it may effect moral leadership and other kind leadership, and overriding alternative descriptions of ethical leadership (Wang et al., 2019). Spiritual leadership has influence on organisational outcomes in consist of membership, empowerment, personal characteristics related meaning and calling (Nguyen et al., 2018). Spiritual leadership has influence in forming more solid ground for organization (Kaya, 2015). The problem in the business unit of Darussalam Gontor University is the understanding of staff who have diverse backgrounds about organizational culture based on the values that have been applied in the business unit of Darussalam Gontor University and spiritual leadership in the business unit of Darussalam Gontor University. Researchers are interested in studying the cultural influence of the organization and spiritual leadership more in the business unit of Darussalam Gontor University. Researchers took the business unit of Darussalam Gontor University as a research objective because this business unit is one of the organizations that uses organizational culture and spiritual leadership in the sale of services.

\section{METHOD}

This research aimed to all employees of the business unit of Darussalam Gontor University from all lines of work regardless of the position of the employees of the business unit of Darussalam Gontor. Population is a generalization region consisting of objects or subjects of a certain quality and characteristics applied by researchers. Thus, the population in this study is all employees of the business unit of The University of Darussalam Gontor with total amounts of 49 employees, therefore the specified number of sampel is all members of the population. This is based on probability sampling with simple random sampling technique that is sampling technique from the population which done randomly without seeing the existing in the population.

Data collection technique began with research instruments. Research instruments are one of the measuring instruments used for observed scientific and social phenomena. This study used questionnaires as a measurement tool for research. Questionnaire is a data collection technique that is done by giving a set of written questions to respondents to fill out the questionnaire that has been given. This type of questionnaire consists of closed question where the answer has been limited by researchers to close the possibility for respondents to answer longer according to their will. The question given to the respondent is a positive question. This study used Likert scale in its data collection. Each of the answers is given a choice of scores. In the Likert scale used five categories of assessment. Among others are strongly agree $=5$; agree $=4$; neutral $=3$; disagree $=2$; strongly disagree $=1$.

A valid instrument means the measuring instrument used to obtain the data is valid. Valid in question means it can be used to measure what should be measured. Reliability concerns the accuracy of measuring instruments whether a measuring instrument is accurate, stable, and consistent in measuring what you want to measure. The technique used to measure reliability is to use the Alpha Cronbach formula as follows.

$$
\mathrm{r}_{11}=\left[\frac{\mathrm{k}}{\mathrm{k}-1}\right]\left[1-\frac{\sum \sigma_{\mathrm{b}}^{2}}{\sigma_{1}^{2}}\right]
$$

A good regression model is if the distribution is normal or close to normal. If the data spreads around the diagonal line and follows the direction of the diagonal line or the histogram graph shows a normal distribution pattern, then the regression model fulfills the assumption of normality. To determine whether there is multicollinearity in the regression model, it can be seen from the VIP value (Variance Inflation Factor) and the tolerance value. If tolerance $>0,10$ or equal to VIP $>10$, the data indicates multicollinearity and vice versa.

Detection of heteroscedasticity can be done by looking at the presence or absence of certain patterns on the scatterplot graph. A good regression model is one that occurs homoscedasticity or one 
that does not occur heteroscedasticity. Heteroscedasticity occurs when there are certain patterns such as dots that form a certain regular pattern (wavy, widened then narrowed). If there is no clear line pattern, and the dots spread above and below the number 0 on the $\mathrm{Y}$ axis, then heteroscedasticity occurs. The autocorrelation test is used to determine whether or not there are deviations from the classical assumption, namely the correlation that occurs between the residuals in one observation and other observations in the regression model. The prerequisite that must be met is the absence of autocorrelation in the regression model. The autocorrelation testing method that is often used is the Durbin-Watson test (DW test). The purpose of the multiple linear regression analysis research is to determine the effect or relationship between the independent variable and the related variables partially or simultaneously. This technique is used to test how much influence partially or simultaneously organizational culture and spiritual leadership on employee performance. This analysis is used to determine how the relationship between the independent variable and the dependent variable. The formula for multiple linear equations is:

$$
\mathrm{Y}=\mathrm{a}+\mathrm{b} 1 \mathrm{X} 1+\mathrm{b} 2 \mathrm{X} 2+\mathrm{e}
$$

The data analysis in this study are classic assumption test, multiple regression analysis, determentation coefficient test, and also $F$ test and $T$ test. The coefficient of determination $\left(\mathrm{R}^{2}\right)$ is basically to find out how much influence the independent variable $(X)$ contributes to the dependent variable (Y). The coefficient of determination is ranging between zero and one. The small value of $\mathrm{R}^{2}$ means that the ability of the independent variables in explaining the variation of the dependent variable is very limited. A value close to one means that the independent variables provide almost all the information needed to predict the variation in the dependent variable. The coefficient of determination can be identified on the regression results. There are two hypothesis testing, namely the $\mathrm{T}$ test and the $\mathrm{F}$ test. The $\mathrm{T}$ test is used to answer the formulation of the problem whether or not there is an influence of organizational culture and spiritual leadership partially on the performance of the employees of the Darussalam Gontor University Business Unit. T tests are used for the purpose of testing each free variable against bound variables. In addition, $\mathrm{T}$ test can be done by looking at the significance value (Sig.) t with a level of significance $(\alpha)=0,05$, with the standards as follow:

a. If probability $>0,05$ then Ho is accepted

b. If probability of $\leq 0,05$ then Ho is rejected

$\mathrm{F}$ Test is used with the aim of testing the entire free variable against bound variables. While the $\mathrm{F}$ test is used to answer the formulation of the problem whether or not the influence of organizational culture and spiritual leadership simultaneously on the performance of the employees of the Darussalam Gontor University Business Unit. The formula of F test is:

$$
\mathrm{F}=\frac{R^{2} / k}{\left(1-R^{2}\right)(N-k-1)}
$$

\section{RESULT \& DISCUSSION}

Normality test results can be found in Figure 1. The image showed there is a linear relationship between spiritual leadership and organizational culture with employee performance in the business unit of University Darussalam Gontor. Based on Figure 1, it can be concluded the regression model is worth using, because the image above shows the data is scattered around the diagonal line and follows the diagonal line and the histogram chart shows the normal distribution pattern. 


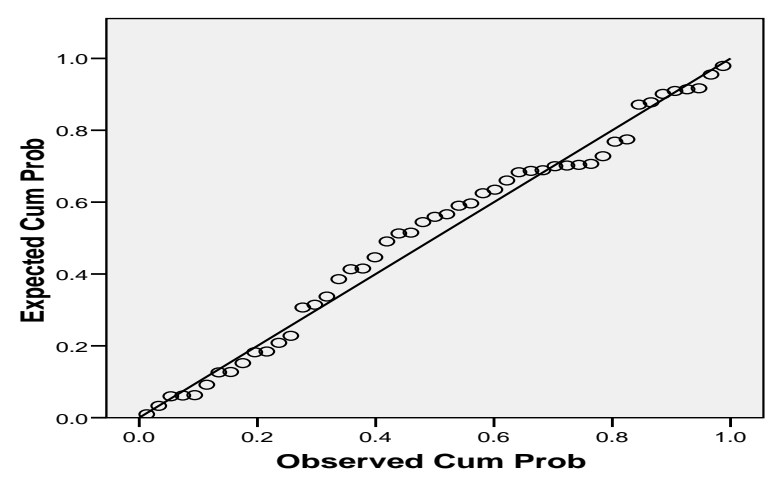

Figure 1 . Normality test result Source: Data analyzed (2020)

Table 1. Multicollinearity test result

\begin{tabular}{|c|c|c|c|c|c|c|c|c|}
\hline \multicolumn{9}{|c|}{ Coefficients $^{a}$} \\
\hline \multirow[b]{2}{*}{ Model } & & \multicolumn{2}{|c|}{$\begin{array}{l}\text { Unstandardized } \\
\text { Coefficients }\end{array}$} & \multirow{2}{*}{$\begin{array}{c}\text { Standardized } \\
\text { Coefficients }\end{array}$} & \multirow[b]{2}{*}{$t$} & \multirow[b]{2}{*}{ Sig. } & \multicolumn{2}{|c|}{ Collinearity Statistics } \\
\hline & & B & Std. Error & & & & Tolerance & VIF \\
\hline \multirow[t]{3}{*}{1} & (Constant) & 15.736 & 9.216 & & 1.707 & .094 & & \\
\hline & Organizational Behaviour & .130 & 270 & .077 & .483 & .632 & .522 & 1.915 \\
\hline & Spiritual Leadership & .766 & .219 & .562 & 3.503 & .001 & .522 & 1.915 \\
\hline
\end{tabular}

a. Dependent Variable: Employee Performance

Source: Data analyzed (2020)

Based on the output table coefficients known the tolerance value for variable cultural organization (X1) and spiritual leadership is 0,522 , greater than 0,10 . While the VIF value for the organizational culture variable (X1) and Spiritual Leadership (X2) is 1,915 < 10. Then it can be concluded that between independent variables did not occur multicolinearity.

Table 2. Validity test result

\begin{tabular}{ccccc}
\hline Variable & Indicator & $\begin{array}{c}\mathrm{R} \\
\text { Counted }\end{array}$ & $\begin{array}{c}\mathrm{R} \\
\text { Table }\end{array}$ & Status \\
\hline & $\mathrm{X} 1.1$ & 0,618 & 0,2816 & Valid \\
& $\mathrm{X} 1.2$ & 0,480 & 0,2816 & Valid \\
& $\mathrm{X} 1.3$ & 0,689 & 0,2816 & Valid \\
Organizational & $\mathrm{X} 1.4$ & 0,722 & 0,2816 & Valid \\
Culture (X1) & $\mathrm{X} 1.6$ & 0,484 & 0,2816 & Valid \\
& $\mathrm{X} 1.7$ & 0,660 & 0,2816 & Valid \\
& $\mathrm{X} 1.8$ & 0,728 & 0,2816 & Valid \\
& $\mathrm{X} 1.9$ & 0,767 & 0,2816 & Valid \\
& $\mathrm{X} 1.10$ & 0,517 & 0,2816 & Valid \\
\hline & $\mathrm{X} 2.1$ & 0,735 & 0,2816 & Valid \\
& $\mathrm{X} 2.2$ & 0,655 & 0,2816 & Valid \\
& $\mathrm{X} 2.3$ & 0,514 & 0,2816 & Valid \\
Spiritual & $\mathrm{X} 2.4$ & 0,408 & 0,2816 & Valid \\
Leadership & $\mathrm{X} 2.5$ & 0,647 & 0,2816 & Valid \\
(X2) & $\mathrm{X} 2.6$ & 0,471 & 0,2816 & Valid \\
& $\mathrm{X} 2.7$ & 0,701 & 0,2816 & Valid \\
& $\mathrm{X} 2.8$ & 0,724 & 0,2816 & Valid \\
& $\mathrm{X} 2.9$ & 0,628 & 0,2816 & Valid \\
& $\mathrm{X} 2.10$ & 0,473 & 0,2816 & Valid \\
& $\mathrm{X} 2.11$ & 0,732 & 0,2816 & Valid
\end{tabular}




\begin{tabular}{ccccc} 
& X2.12 & 0,617 & 0,2816 & Valid \\
\hline & Y.1 & 0,585 & 0,2816 & Valid \\
& Y.2 & 0,660 & 0,2816 & Valid \\
& Y.3 & 0,581 & 0,2816 & Valid \\
& Y.4 & 0,754 & 0,2816 & Valid \\
& Y.5 & 0,707 & 0,2816 & Valid \\
Employee & Y.6 & 0,650 & 0,2816 & Valid \\
Performance & Y.7 & 0,572 & 0,2816 & Valid \\
(Y) & Y.8 & 0,624 & 0,2816 & Valid \\
& Y.10 & 0,624 & 0,2816 & Valid \\
& Y.11 & 0,377 & 0,2816 & Valid \\
& Y.12 & 0,647 & 0,2816 & Valid \\
& Y.13 & 0,693 & 0,2816 & Valid \\
& Y.14 & 0,488 & 0,2816 & Valid \\
& Y.15 & 0,513 & 0,2816 & Valid \\
\hline
\end{tabular}

Source: Data analyzed (2020)

Based on the Table 2, the validity test results showed that no statement items are declared unvalid because the $r$ count obtained is greater than the $r$ table $(0,2816)$. $R$ table can be seen in product moment table with formula $n-2$ with error degree of $5 \%$. Therefore, it has a larger $r$ count than the $r$ table.

Table 3. Reliability test result

\begin{tabular}{lccl}
\hline \multicolumn{1}{c}{ Variable } & $\begin{array}{c}\text { Alpha- } \\
\text { Cronbach }\end{array}$ & R Table & Status \\
\hline Organizational Culture $(\mathrm{X} 1)$ & 0,784 & 0,2816 & Reliable \\
\hline Spiritual Leadership $(\mathrm{X} 2)$ & 0,750 & 0,2816 & Reliable \\
\hline Employee Performance $(\mathrm{Y})$ & 0,751 & 0,2816 & Reliable \\
\hline
\end{tabular}

Source: Data analyzed (2020)

Based on Table 3, it is known that all variables have an Alpha-Cronbach value of more than 0,60, hence the three variables are declared. Known Cronbach alpha values of organizational culture $(0,784)$, spiritual leadership $(0,750)$, and employee performance $(0,751)$, are greater than $0,2816(\mathrm{r}$ tables). Based on those results, it can then be concluded that the questionnaire is declared reliable or trusted as a data collection tool in this study.

Table 4. Multiple regresion analysis

\begin{tabular}{lccccc}
\hline \multirow{2}{*}{ Model } & \multicolumn{2}{c}{$\begin{array}{c}\text { Coefficients }^{\mathbf{a}} \\
\text { Unstandardized } \\
\text { Coefficients }\end{array}$} & $\begin{array}{c}\text { Standardized } \\
\text { Coefficients }\end{array}$ & T & Sig. \\
\cline { 2 - 4 } & $\mathrm{B}$ & Std. Error & Beta & & \\
\hline (Constant) & 15,736 & 9,216 & & 1,707 & 0,094 \\
Organizational Culture & 0,130 & 0,270 & 0,077 & 0,483 & 0,632 \\
Spiritual Leadership & 0,766 & 0,219 & 0,562 & 3,503 & 0,001 \\
a. Dependent Variable: Employee Performance & & & & &
\end{tabular}

Source: Data analyzed (2020)

Based on Table 4, the multiple regression equation is described as follows:

$\mathrm{a}=15,736$ means that if the free variable $(\mathrm{X} 1, \mathrm{X} 2)$ does not exist or is in a constant state, then the employee's performance will reach 15,736. Assuming that factors other than the model discussed are in a constant state or $=0 ; b 1=0,130$ means that the organizational cultural variable has a coefficient 180 
of 0,130 indicating that this variable positively affects employee performance, in the sense that if the culture of the organization is improved by 1 unit, then employee performance will increase by 0,130 units, where other factors outside of this model are discussed in a constant state or $=0$. This indicates if the Business Unit of Darussalam Gontor University improves the cultural system of the organization, then this variable will further affect the performance of employees of the Business Unit of Darussalam Gontor University. Students, lecturers, and academicians show more behavior related to altruistic love than beliefs and visions. It is recognized that faculty members do not display the quality of leadership enough for students (Polat, 2011). Assuming that factors other than the model discussed are in a constant state or $=0 ; \mathrm{b} 2=0,766$ means that the spiritual leadership variable has a coefficient of 0,766 indicating that this variable has a positive effect on employee performance. In the sense that if spiritual leadership is improved by 1 unit, then employee performance will increase by 0,766 units, where other factors beyond the model discussed are in a constant state or 0 . This indicates that if the Business Unit of Darussalam Gontor University improves spiritual leadership, then this variable will further affect the performance of employees of the Business Unit of Darussalam Gontor University. Spiritual leadership has a significant effect on employee performance. In totality, the findings of this research suggest that spiritual leadership enhances employee performance to achieve organizational competitive advantage (Udin, 2019).

Table 5. Coefficient of determination

\begin{tabular}{|c|c|c|c|c|}
\hline \multicolumn{5}{|c|}{ Model Summary } \\
\hline Model & $\mathrm{R}$ & R Square & Adjusted R Square & $\begin{array}{l}\text { Std. Error of } \\
\text { the Estimate }\end{array}$ \\
\hline 1 & $0,618^{\mathrm{a}}$ & 0,382 & 0,355 & 4,907 \\
\hline \multicolumn{5}{|c|}{$\begin{array}{l}\text { a. Predictors: (Constant), Spiritual Leadership, Organizational } \\
\text { Culture }\end{array}$} \\
\hline
\end{tabular}

Source: Data Analyzed (2020)

Based on the Table 5, it can be known that $\mathrm{R}^{2}$ in the Business Unit of Darussalam Gontor University is 0,382 . This suggests that $38,2 \%$ of employee performance variables are explained by organizational cultural variables and spiritual leadership. Meanwhile, $61,8 \%$ was affected by other variables not included in the regression model.

Table 6. ANOVA Table

\begin{tabular}{lccccc}
\hline Model & \multicolumn{5}{c}{ ANOVA $^{\mathbf{a}}$} \\
& $\begin{array}{c}\text { Sum of } \\
\text { Squares }\end{array}$ & df & $\begin{array}{c}\text { Mean } \\
\text { Square }\end{array}$ & F & Sig. \\
\hline Regression & 684,292 & 2 & 342,146 & 14,207 & $0,000^{\mathrm{b}}$ \\
1 Residual & 1107,830 & 46 & 24,083 & & \\
\multicolumn{7}{l}{ Total } & 1792,122 & 48 & & \\
a. Dependent Variable: Employee Performance \\
b. Predictors: (Constant), Spiritual Leadership, Organizational \\
\hline
\end{tabular}

Source: Data Analyzed (2020)

Based on Table 6, the results of the statistical calculation show the value of $F$ count is 14,207 while the $\mathrm{F}$ table can be known from the calculation of 3,20 then it is seen that $\mathrm{F}$ calculates 14,207 > F table 3,20 with an error degree of $5 \%$. Therefore, it can be concluded that together the cultural variables of the organization and spiritual leadership have a significant effect on employee performance. Workplace spirituality helps individuals identify the meaning and purpose of their work, builds an inner bond through developing long-term bonds with the workplace, and strengthen employee teamwork performance (Indradevi, 2020). The personality of the institution is like proof of the organization's self, which is meant as a substantial point of the institution's energy in the 
manufacturing process which displays 2 issues, namely: the growth of scientific traditions and a clean management system of Islamic boarding schools (Mardiyah, 2012).

Table 7. F-test result

\begin{tabular}{|c|c|c|c|c|c|c|}
\hline \multirow{3}{*}{\multicolumn{2}{|c|}{ Model }} & \multicolumn{2}{|c|}{ Coefficients $^{\mathrm{a}}$} & \multirow{3}{*}{$\begin{array}{c}\text { Standardized } \\
\text { Coefficients } \\
\text { Beta }\end{array}$} & \multirow{3}{*}{$\mathrm{t}$} & \multirow{3}{*}{ Sig. } \\
\hline & & \multicolumn{2}{|c|}{$\begin{array}{l}\text { Unstandardized } \\
\text { Coefficients }\end{array}$} & & & \\
\hline & & $\mathrm{B}$ & Std. Error & & & \\
\hline \multirow{3}{*}{1} & (Constant) & 15,736 & 9,216 & & 1,707 & 0,094 \\
\hline & Organizational Culture & 0,130 & 0,270 & 0,077 & 0,483 & 0,632 \\
\hline & Spiritual Leadership & 0,766 & 0,219 & 0,562 & 3,503 & 0,001 \\
\hline \multicolumn{7}{|c|}{ a. Dependent Variable: Employee Performance } \\
\hline
\end{tabular}

Source: Data Analyzed (2020)

Based on Table 7, the significant value (sig.) of the organization's cultural variable is 0,632 . While the significant value of the spiritual leadership variable is 0,001 . Since the significant value of the organization's cultural variable is $0,632>$ probability 0,05 , it can be concluded that $\mathrm{H} 1$ or the first hypothesis was rejected. While the significant value of the spiritual leadership variable is $0,001<$ probability 0,05 , it is concluded that $\mathrm{H} 2$ or the second hypothesis is accepted. We can conclude that organizational culture has less effect on employee performance, while spiritual leadership has an influence on employee performance. This then allows us to contribute to the spiritual aspects of spiritual leadership theory by describing the spiritual norms in employee performance by a person leader (Benefiel, 2005). Spiritual leadership also has a direct effect on employee behavior (Malik et al., 2018).

Organization's culture has a positive but insignificant effect on employee performance. This is evidenced by statistically significant test value for the organizational cultural variable is sig. 0,632 > probability 0,05 then it can be concluded that $\mathrm{H} 1$ or the first hypothesis is rejected. It can be stated that organizational cultural variables do not have a significant influence on employee performance. This research's results related with Puspitasari (2019) and also Kakiay (2017) which stated there is influence between spiritual leadership and performance. The organizational culture that exists in a company is a fixed rule or a value system that must be carried out by every employee, because for them, regardless of the organizational culture, whether the rules that must be obeyed or the activities that must be carried out, they will still adhere to and carry out the cultural organization (Violita, 2018). Spiritual leadership variables show that spiritual leadership has a positive and significant effect on employee performance. This is evidenced by statistically significant value for spiritual leadership variables is $0,001<$ probability 0,05 , then it is concluded that $\mathrm{H} 2$ or the second hypothesis is accepted. It can be stated that spiritual leadership variables have a significant influence on employee performance. Spiritual leadership offers promise as a steppingstone for a new paradigm for leadership theory in business or organization. Business research and application consider to mixing and expanding transformational also charismatic theories, ethics, values-based theories, for example, authentic and servant leadership. Spiritual leaership also staying away from specification errors measurement model (Fry et al., 2005)

\section{CONCLUSION \& RECOMMENDATION}

Based on the analysis and discussion of this study, it can be drawn the following conclusions: partially the culture of the organization does not have a significant influence on the performance of the Business Unit of Darussalam Gontor University. In part, spiritual leadership has significant significance to the performance of employees of the Business Unit of Darussalam Gontor University. Based on the F test (simultaneously), the cultural variables of the organization and spiritual leadership has a significant influence together on the performance of employees of the Business Unit of 
Darussalam Gontor University. Spiritual leadership variables are the most dominant variables affecting the performance of employees of the Business Unit of Darussalam Gontor University.

\section{REFERENCES}

Alimudin, A., Septiani, D., Sasono, A. D., \& Wulandari, A. (2017). Effect of spiritual leadership to organizational culture and employee's loyalty (A case study in the society's eye hospital, East Java). Jurnal Terapan Manajemen dan Bisnis, 3(2), 76-86. https://Doi.Org/Doi: $10.26737 / \mathrm{Jtmb} . \mathrm{V} 3 \mathrm{i} 2.210$

Benefiel, M. (2005). The Second half of the journey: Spiritual leadership for organizational $\begin{array}{llll}\text { transformation. } & \text { Leadership } & \text { Quarterly, } & \text { 76(5), }\end{array}$ Https://Doi.Org/10.1016/J.Leaqua.2005.07.005

Fry, L.W., Vitucci, S., \& Cedillo, M. (2005). Spiritual leadership and army transformation: Theory, measurement, and establishing a baseline. The Leadership Quarterly, 16(5), 835-862. https://Doi.Org/10.1016/J.Leaqua.2005.07.012

Indradevi, R. (2020). Workplace spirituality: Successful mantra for modern organization. Journal of Critical Reviews, 7(6), 437-440. Https://Doi.Org/Doi: 10.31838/Jcr.07.06.77

Kakiay, A. N. (2017). Pengaruh kepemimpinan spiritual dan kepuasan kerja terhadap kinerja guru. Jurnal Psikologi, 10(2), 148-151. https://ejournal.gunadarma.ac.id/index.php/psiko/article/view/ 1783

Kaya, A. (2015). The relationship between spiritual leadership and organizational citizenship behaviors: A research on. in edam (Ed.), Iv. Education Management Forum, 15(Issue October 2013), Pp. 597-606. https://Doi.Org/10.12738/Estp.2015.3.1988

Kuswati, Y. (2020). The influence of organizational culture on employee performance. Budapest International Research and Critics Institute (Birci-Journal): Humanities and Social Sciences, 3(1), 296-302. https://Doi.Org/10.33258/Birci.V3i1.761

Malik, R., Yadav, J., \& Yadav, D. (2018). Role of spiritual leadership in enhancing employees' job performance: A study of organized retail sector in India. International Journal of Innovative Technology and Exploring Engineering, 8(2s), 122-128. https://www.ijitee.org/wp-content/ uploads/papers/v8i2s/BS2687128218.pdf

Mardiyah, M. (2012). Kepemimpinan kiai dalam memelihara budaya organisasi di Pondok Modern Gontor, Lirboyo Kediri, dan Pesantren Tebuireng Jombang. Tsaqafah, 8(1), 67. https://Doi.Org/10.21111/Tsaqafah.V8i1.21

Mehta, Y., \& Joshi, S. (2010). Impact of workplace spirituality on organization culture through improved employee productivity. AIMS International Conference on Value-Based Management, 63(3), 221-226. http://www.aims-international.org

Nguyen, P. V., Tran, K. T., Dao, K. H., \& Dinh, H. P. (2018). The role of leader's spiritual leadership on organisation outcomes. Asian Academy of Management Journal, 23(2), 45-68. https://Doi.Org/10.21315/Aamj2018.23.2.3

Polat, S. (2011). The level of faculty members' spiritual leadership (si) qualities display according to students in faculty of education. Procedia - Social and Behavioral Sciences, 15, 2033-2041. https://Doi.Org/10.1016/J.Sbspro.2011.04.049

Puspitasari, S. (2019). Pengaruh kepemimpinan spiritual terhadap kepuasan kerja karyawan melalui motivasi intrinsik dan komitmen organisasi (Studi kasus Rumah Sakit Islam Sultan Agung, Semarang). Jurnal Ekonomi dan Bisnis, 20(1), 73. https://Doi.Org/10.30659/Ekobis.20.1.73-84

Reave, L. (2005). Spiritual values and practices related to leadership effectiveness. Leadership Quarterly, 16(5), 655-687. Https://Doi.Org/10.1016/J.Leaqua.2005.07.003

Samul, J. (2020). Spiritual leadership: Meaning in the sustainable workplace. Sustainablity, 12(1), 267. https://Doi.Org/10.3390/Su12010267

Scott, P. H., \& Tweed, S. (2016). Implications of spiritual leadership on organizations. Journal of $\begin{array}{llll}\text { Education } \quad \text { S } & \text { Social }\end{array}$ http://Jespnet.Com/Journals/Vol_3_No_6_December_2016/10.Pdf

Soleh, A. L. (2018). Analisis pengaruh kompensasi dan budaya organisasi terhadap kinerja karyawan dengan motivasi sebagai variabel intervening (Undergraduate's Thesis). http://ERepository.Perpus.Iainsalatiga.Ac.Id/4871/1/Skripsi Aris Lukman Saleh.Pdf

Udin, U. (2019). Spiritual leadership and employee performance: An empirical investigation. International Journal of Business Management and Economic Review, 2(5), 54-61. 
Jurnal Manajemen Maranatha घ Vol. 20 Nomor 2, Mei (2021)

https://Doi.Org/10.35409/Ijbmer.2019.2420

Violita, D. (2018). Pengaruh gaya kepemimpinan spiritual dan budaya organisasi terhadap kinerja karyawan pada Hotel 88 Embong Malang di Surabaya. 74. http://Digilib.Uinsby.Ac.Id/Id/Eprint/26366

Wang, M., Guo, T., Ni, Y., Shang, S., \& Tang, Z. (2019). The effect of spiritual leadership on employee effectiveness: An intrinsic motivation perspective. Frontiers in Psychology, 9(1), 1-11. https://Doi.Org/10.3389/Fpsyg.2018.02627 